\title{
Nebulization Criteria and Quantification
}

\author{
Nardos Hailu ${ }^{1}$, Michiel Postema ${ }^{2}$ (D) Ondrej Krejcar ${ }^{3}$ (D) and Dawit Assefa ${ }^{1,3, *(D)}$ \\ 1 Center of Biomedical Engineering, Addis Ababa Institute of Technology, Addis Ababa University, \\ King George VI Street, Old Pharmacy Building, Rm. 102, P.O. Box: 385, Addis Ababa, Ethiopia; \\ nardoshailu111@gmail.com \\ 2 School of Electrical and Information Engineering, Chamber of Mines Building, University of the \\ Witwatersrand, Johannesburg, 1 Jan Smuts Laan, Braamfontein 2050, South Africa; \\ michiel.postema@wits.ac.za \\ 3 Faculty of Informatics and Management, Center for Basic and Applied Research, University of Hradec \\ Kralove, Rokitanskeho 62, 50003 Hradec Kralove, Czech Republic; ondrej.krejcar@uhk.cz \\ * Correspondence: dawit.assefa@aau.edu.et; Tel.: +251-922759688
}

Received: 23 March 2020; Accepted: 23 May 2020; Published: 6 June 2020

\begin{abstract}
The application of atomization technology is common in fields such as agriculture, cosmetics, environmental sciences, and medicine. Aerosolized drugs are administered using nebulizers to treat both pulmonary and nonpulmonary diseases. The characterization and measurement of nebulizers are of great significance in analyzing the performance and accuracy of the nebulizing system and the advancement of the technology. Nevertheless, the characterization of aerosols has been a long-standing challenge in scientific disciplines ranging from atmospheric physics to health sciences. The study of factors that influence nebulization has not been undertaken systematically using experimental techniques. Numerical modeling (NM) and computational fluid dynamics (CFD) can address such issues. This article provides a concise overview of the literature on the application of computational fluid dynamics to medical nebulizers and aerosol measurements.
\end{abstract}

Keywords: aerosol formation; atomization; nebulizer; spraying; droplet size measurement

\section{Introduction}

Atomization is the process of disintegrating fluids into liquid spray droplets due to the cohesive and disruptive forces acting on the liquid. Atomization can be achieved through different techniques, which can be classified into five categories: pressure, air-assisted or pneumatic, mechanical, acoustic, and thermal atomizers [1-4]. Pressure and air-assisted atomizers both utilize the kinetic energy of the fluid itself so that the relative velocity of the surrounding air and the fluid is kept high. Pressure atomizers use high pressure to force the fluid through the nozzle, and the friction that is created between the fluid and the air causes the fluid to disrupt and form droplets. For example, a pressure swirl atomizer exists that utilizes a three step process: film formation, sheet breakup, and atomization. In this atomizer, a special nozzle called a swirl port is used to push the liquid against the wall of the chamber, and the liquid emerges from the orifice as a sheet, which is unstable and soon breaks up into droplets [5]. In the case of air-assisted atomization, the fluid emerging from the atomizer is surrounded with a high speed stream of air. Due to the friction caused between the fluid and air, droplets are created. In the third type, i.e., mechanical atomizers, external energy is applied; one example of this is the rotary atomizer. In this device, a centrifugal force is used to spread the liquid uniformly. The energy creates a high relative speed between the liquid and air, which causes the liquid to change into droplets [1]. The fourth type, i.e., the acoustic atomizer, operates based on the principle of acoustic vibrations caused by gas flow with a velocity on the fluid field. The technique is very similar to pneumatic atomizers except that it uses a different type of gas energy and has a better quality 
atomization. The last type, thermal atomization, is a technique of coating in which materials are sprayed onto a surface. One good example is the cold spray thermal atomizer. Cold spray thermal atomizers involve accelerating solid particles to high velocities in a supersonic jet. First, the material is injected and heated by high temperature gas and begins to melt, before being accelerated. Afterwards, it is sprayed onto a substrate at a relatively high velocity [6]. The use of cold spray atomizers is rapidly becoming more widespread due to their ability to deposit fluids while keeping the chemical composition of the fluid intact. Thermal spraying processes can be further categorized into three classes based on the type of energy they use, namely the energy evolving from gas expansion, electrical energy, and combustion heat sources [6]. Spraying has been widely used in different disciplines such as production and process engineering, treatment and environmental protection, the metallurgy and coating industries, medical spraying, printing, and agricultural spraying [7].

One application of medical spraying is inhalation therapy. Inhalation therapy devices are medical devices that convert liquid drugs into aerosols or fine mists. An aerosol is a two-phase system composed of liquid or solid particles and a gaseous medium in a suspension. Inhalation therapy has significantly improved the treatment of pulmonary as well as nonpulmonary diseases [8-12]. Administering drugs in the form of aerosols has been proven to be effective for several reasons, such as faster onset action, reduced drug requirement to attain the desired therapeutic effect, and lower side effects due to minimal exposure to the rest of the body. Broadly speaking, three types of devices are used to deliver drugs in the form of aerosols: pressurized metered dose inhalers (pMDIs), dry powder inhalers (DPIs), and nebulizers. The pMDI is a portable outpatient inhalation device most widely used to deliver a specific amount of drug to treat local respiratory diseases. On the other hand, a DPI is a portable inhaler device that is used to deliver drugs in the form of a dry powder. The third inhalation device, the nebulizer, is a medical drug delivery device used to convert liquids into aerosols of small size that can be inhaled into the lower respiratory tract [13-20].

Although DPI and pMDI are the most widely used drug delivery systems, they are inadequate in various scenarios, such as when used by elderly people and for patients with low inspiratory flow rates. On the other hand, nebulizers, which are the oldest systems to deliver drugs, overcome such problems [21,22]. Furthermore, since most drugs are available in solution form, patients are becoming more satisfied with nebulizers $[23,24]$. However, nebulizers require more time to aerosolize and are bulky and, therefore, not portable [25].

The primary aim of the current study was to assess the use of computational fluid dynamics (CFD) in medical nebulizers focusing on their characterization and measurement.

\subsection{Medical Nebulizers}

Medical nebulizers are devices that aerosolize drugs so that they can be inhaled into the lower respiratory tract. Nebulization is a method of administering drugs by converting the solution into aerosols. Several research studies have been carried out in the literature showing the effectiveness of nebulizers in treating different illness conditions such as pneumonia, asthma, cystic fibrosis, lung injury, and dyspnea [26-29]. A variety of medications such as $\$ 2$-agonist drugs, corticosteroids, anticholinergic drugs, and antiasthma drugs are available in a form suitable for nebulization [30].

Depending on the method of production of aerosols, medical nebulizers are categorized into three classes: jet, ultrasonic, and mesh nebulizers [31]. Jet nebulizers are the most widely used type for the treatment of pulmonary diseases. They use electrical power sources or gas compressors in order to break the solution into tiny droplets, and a baffle is used as a filter to limit the size of the droplets. However, jet nebulizers are bulky. Additionally, the baffle allows only $12 \%$ of the drug to reach the lungs, while the rest is wasted [32]. Conversely, ultrasonic nebulizers utilize sound waves to break up the drug solution. They involve piezoelectric crystals to convert electrical energy from the source into oscillations, varying from moderate to high, to form the droplet. Although ultrasonic nebulizers are more compact and efficient when compared to jet nebulizers, proteins, liposomes, suspensions, and other drugs that are vulnerable to deformity cannot be delivered in this way [33-36]. The third 
and most recent type of nebulizer is the mesh nebulizer. This type utilizes micropump technology and a number of pores that can be adjusted for drugs with different properties. It has been shown that proteins, suspensions, and nucleic acids can be delivered using mesh nebulizers without any deformation. This is due to the alleviation of heating attained by using lower frequency waves [37-40]. Although mesh nebulizers are becoming the first choice in the treatment of different diseases, there are still a number of challenges faced during the delivery of viscous drugs [41-45].

\subsection{Nebulizer Characterization}

The objective of the aforementioned nebulization methods is to produce aerosol droplets that can bypass the upper airway and be deposited in the lower respiratory tract. This determines the effectiveness of the drug inhalation treatment [16]. Targeted drug delivery is important in increasing therapy efficiency while alleviating side effects. As research shows, the droplet size distribution and traveling velocity of the aerosols are the two most important factors of nebulization treatment. The droplet size determines its chance of penetrating the lower respiratory tract, and aerosol velocity in turn determines the droplet size; an increase in velocity generally decreases the aerosol size [46,47].

There are different types of forces that govern the deposition of drug droplets of different sizes [48]. According to previous research, droplets in the range of 1-5 micrometers can be delivered to the smaller airways and alveoli directly due to sedimentation forces, while submicronics of below 1 micrometer in size are not deposited in the right location and are exhaled due to Brownian motion. Particles larger than 5 micrometers are most likely to deposit in the larger conducting airways due to a relative high mass deposit by inertial impaction [48,49]. This means that the deposition characteristics of droplets in the alveolar region, airways, mouth, and throat and other parts of the body depend heavily on particle size [45]. It is noted that the size and velocity of the droplets are affected by different factors including the breathing mode of the patient, the nebulizer system, the geometry of the nozzle, and the aerosol properties [50-52].

\section{Literature Review on Nebulization}

The systematic literature review carried out in the current study comprises two parts. The first part is a review of scientific publications on the factors that influence nebulization, while the second part is an overview of technologies used to measure the outputs of nebulizers, specifically droplet size and velocity.

\subsection{Methods}

\subsubsection{Search Strategy and Eligibility Criteria}

This systematic literature review was done in September 2019 on Scopus and Web of Knowledge. In the Scopus database, the keywords included were "NEBULA" "AND" "COMPUTATIONAL FLUID DYNAMICS" "OR" "NUMERICAL MODELLING". A total of 99 studies were found after the search, and the list was further refined to include only those recent works published between 2005 and 2019 and that excluded 9 from the list. Only articles and review papers were considered during the review, and that further excluded 11 of the papers. Out of the remaining 79 papers, 4 were written in languages other than English and hence were discarded. The remaining 75 papers were included in the final review.

The second electronic search was done on the Web of Knowledge database. The keywords used in the electronic search were "NEBULA" "AND" "COMPUTATIONAL FLUID DYNAMICS" "OR" "NUMERICAL MODELING" "AND" "MEDICATION". A total of 144 studies were found during the search. Studies were included based on the same criteria used for the Scopus database search. Accordingly, 112 studies were retained in the final review.

Beside for the two databases, 18 additional articles were identified from other sources. 


\subsubsection{Data Extraction and Study Quality Evaluation}

Data extraction from the two databases was based on authors list, title, DOI (if available), and abstract. A study was considered eligible if it was published between 2005 and 2019, written in the English language, and addressed topics related to a mathematical model or optimization of nebulizers and CFD on aerosol drug delivery. According to the above mentioned criteria, 205 papers were found eligible. These papers were further analyzed based on their conceptual relevance. The process of searching and paper selection is presented on the PRISMA diagram shown in Figure 1.

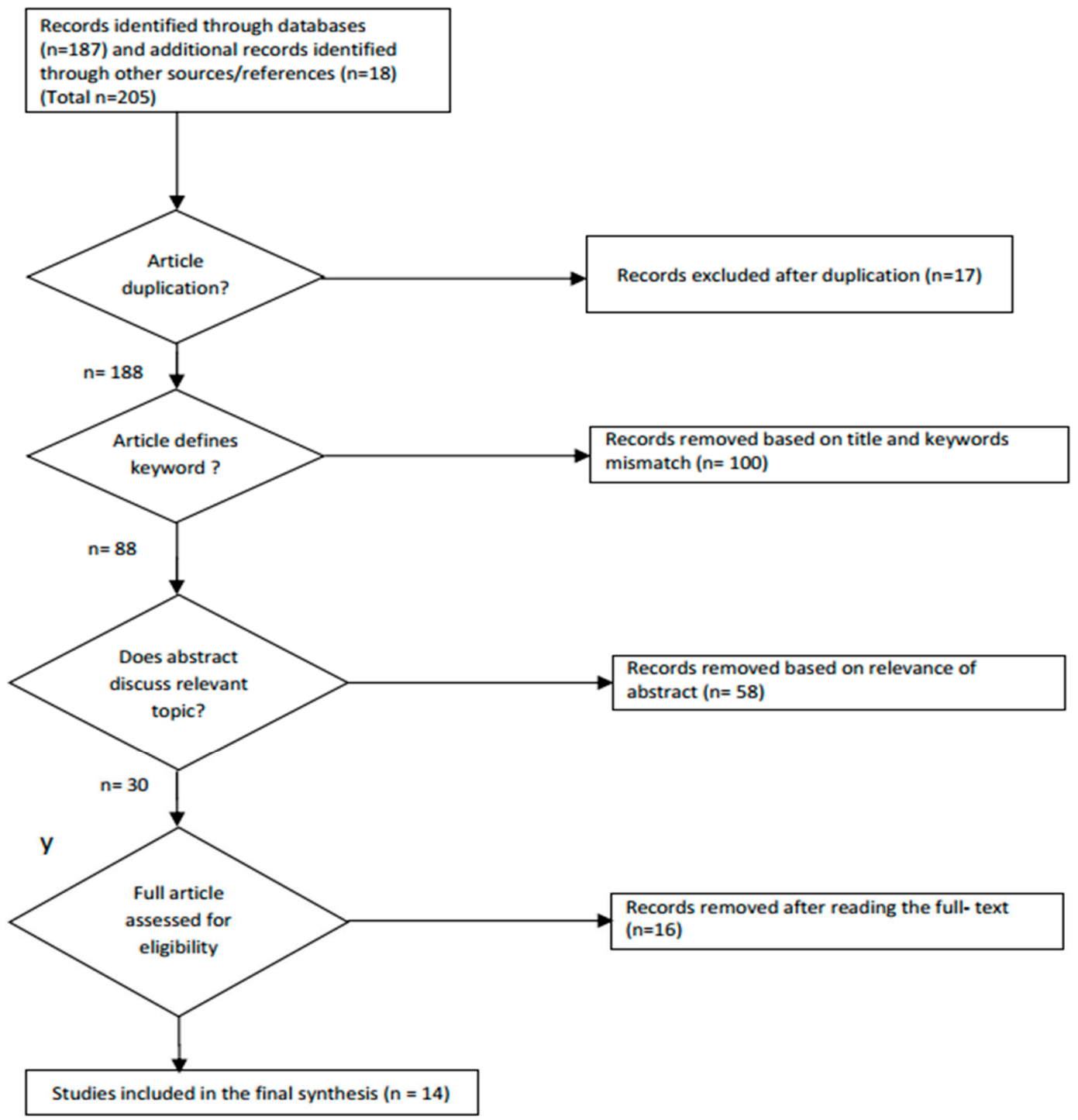

Figure 1. PRISMA diagram used during the systematic literature review.

In accordance with the PRISMA flow diagram, the total number of records identified through searching was 205 out of which 17 duplications were identified and removed. Furthermore, articles were checked if they addressed the defined keywords, and 88 papers were later retained. Only 30 papers had abstracts relevant to the search criteria. Overall, 14 papers were included in the final synthesis after assessing the contents of the 30 articles, out of which 12 were articles focusing on the effects of drug properties and nebulization systems on the efficacy of drug delivery, and 2 papers were reviews on the use of CFD on inhaler devices. 


\subsection{Influencing Factors}

As discussed earlier, the effectiveness of a nebulizer therapy is determined by how much of the drug bypasses the airway and deposits in the lung. The deposition location is determined by the size and velocity of the delivered drug [51]. These two parameters are influenced by a number of factors. Haddrell et al. stated that formulation of drugs, the process occurring between aerosol generation and deposition, as well as the delivery devices play a key role in the atomization process affecting the droplet size and velocity [53]. Extensive understanding and characterization of these factors is required in order to improve the nebulization performance [48]. These factors were classified into three categories in a previous study [52]. Table 1 summarizes the factors.

Table 1. Factors influencing outputs of nebulizers.

\begin{tabular}{lll}
\hline \multicolumn{1}{c}{ Particle Characteristics } & \multicolumn{1}{c}{ Nebulizer System } & \multicolumn{1}{c}{ Patient Condition } \\
\hline Diameter & Residual volume & Airway obstruction \\
Shape & Continuous delivery & Respiratory rate \\
Tap density & Baffle design & Reduced vital capacity \\
Bulk density & Flow rate & Nebulization time \\
Charge & Pressure & Occluded airways \\
Hydroscopy & Frequency & Residence time \\
Surface tension & & Nasal breathing \\
Viscosity & & Nozzle insertion angle \\
Concentration effect & & \\
Mass median diameter & & \\
\hline
\end{tabular}

Traditionally, studying and characterizing such factors was limited to experimental observations. Due to the requirement of expensive set up of equipment to capture complex physics, the approach was considered very costly. The other constraint of this method is that it provides only an overall explanation of the process. On the other hand, numerical simulations offer an elaborated explanation and statistical data of different determining factors. Ashgriz et al. investigated the different numerical simulation techniques to deal with atomizers [54]. Nowadays, the use of numerical methods to study inhaler devices is becoming very common due to the emergence of new software. The use of computer based simulations has become very common in all science and engineering fields in the analysis of fluid flows [55]. This is due to the availability of powerful and cheap software. For inhaler therapy technologies, the use of CFD and DEM (discrete element modelling) has helped in overcoming several problems by providing detailed description of extracted statistical data from continuity, momentum, and energy equations [56]. Assuming a flow inside a nozzle with a given geometry, the transport of mass and momentum is described by the (density based) Navier-Stokes equation. The velocity, pressure, and density fields are obtained from the continuity, momentum, energy, as well as the equation of state given in Equations (1)-(5) (in the case of 2D), as also explained in [55].

$$
\text { Continuity equation : } \frac{\partial \rho}{\partial t}+\nabla \cdot(\rho \mathbf{u})=0
$$

Momentum in the x-direction : $\frac{\partial(\rho u)}{\partial t}+\nabla \cdot(\rho u \mathbf{u})=-\frac{\partial p}{\partial x}+\nabla \cdot(\mu \nabla u)+S_{M_{x}}$

Momentum in the y-direction: $\frac{\partial(\rho v)}{\partial t}+\nabla \cdot(\rho v \mathbf{u})=-\frac{\partial p}{\partial y}+\nabla \cdot(\mu \nabla v)+S_{M_{y}}$

$$
\text { Energy equation : } \frac{\partial(\rho e)}{\partial t}+\nabla \cdot(\rho e \mathbf{u})=-p \nabla \cdot \mathbf{u}+\nabla \cdot(k \nabla T)+\varnothing+S_{E}
$$

$$
\text { Equation of state }: p=\rho R T \text { and } e=C_{v} T
$$


where $\rho$ denotes the fluid density $\left(\mathrm{kg} / \mathrm{m}^{3}\right), \mu$ denotes the fluid dynamic viscosity (mPa s), $\mathbf{u}$ is the fluid velocity vector $(\mathrm{m} / \mathrm{s}), u$ is the fluid velocity in the $x$-direction $(\mathrm{m} / \mathrm{s}), v$ is the fluid velocity in the $y$-direction $(\mathrm{m} / \mathrm{s}), p$ represents the fluid pressure $(\mathrm{Pa}), e$ is the specific internal energy $(\mathrm{J} / \mathrm{kg}), k$ is the fluid thermal conductivity $(\mathrm{W} /(\mathrm{m} \mathrm{K})), T$ is the fluid temperature $(\mathrm{K}), R$ is the universal gas constant $\left(\mathrm{m}^{3} \mathrm{~Pa} /(\mathrm{K} \mathrm{mol})\right), C_{v}$ is the heat capacity at constant volume $(\mathrm{J} / \mathrm{K}), S_{M}$ and $S_{E}$ are the momentum and energy source terms, respectively, and $\varnothing$ represents the dissipation function [57]. In practical inhaler design applications, the time averaged versions of these governing equations, the so called Reynolds-averaged Navier-Stokes (RANS) equations, are used.

Aerosol particles often assume considerable inertia depending on their size, which results in wall deposition phenomena. There are also interactions between different aerosol particles that need to be taken into account, and such particle dynamics need to be considered in CFD models. However, traditional CFD techniques may not accurately account for such particle-particle and particle-wall interactions, and DEMs are often preferred in this regard [55,56]. In order to solve the governing Navier-Stokes equations, we need to specify boundary conditions. The typical boundary conditions are input, output, wall, symmetry, and periodic conditions. Different types of boundary conditions can be imposed on the boundary of the domain. The choice of the boundary conditions dictates the resolution of the computational problem. The wrong imposition of boundary conditions may lead to convergence to a wrong solution or complete divergence to the result.

In the current review, recent papers that studied different influencing factors of nebulizer outputs using numerical methods were considered.

Wong et al. [55] and Ruzycki et al. [56] reviewed studies that used CFD to study different inhaler devices. In the reviews, studies from 2005 to 2013 were included. The papers concluded that the use of CFD is a promising technique in order to analyze and design inhaler devices.

As mentioned earlier in Table 1, the properties of drugs is one of the factors determining the output of nebulizers. Labris et al. stated that physical properties such as surface tension, viscosity, ionic strength, temperature, and $\mathrm{pH}$ have effects on size and traveling velocity of particles [25]. Effects of $\mathrm{pH}$ and drug concentration were also studied in [58]. The study discussed that a high concentration of drugs might be a cause for drug output reduction. In addition, a low $\mathrm{pH}$ solution might induce coughing and irritation of the patient's lung. The temperature of the aerosolized drug greatly determines the aerosolization process. Cold aerosols are not beneficial for infants, patients with allergy, and hypersensitive patients. Increase in temperature reduces the quantity of large droplets and decreases the liquid viscosity [59]. Viscosity also has a major impact in atomization. A study presented in [60] showed that the increase in shear and extensional viscosity increases droplet size. Especially, extension viscosity has a key role in the process. The effects of shear and extension viscosity were investigated on atomization of Newtonian and non-Newtonian fluids [61]. For Newtonian fluids, increased viscosity caused a decrease in the number of smaller droplets and an increase in the number of larger droplets. On the other hand, for non-Newtonian fluids, increased viscosity caused more smaller size droplets, while the larger ones disappeared.

Jeng et al. used a micromachine fabricated piezoelectrically actuated nebulizer to investigate the optimal operating conditions and effects of drug properties on their deposition and dispersion [62]. The study investigated effects of drug properties such as surface tension and viscosity on the drug delivery efficacy under a fixed operating frequency. Results of the study showed that as the viscosity of the drug was elevated, average particle size increased and flow rate decreased. On the other hand, as the surface tension of the drug increased, the droplet accumulation around the orifice plate increased.

Furthermore, Arulmuthu et al. studied the aerosolization of shear sensitive plasmid DNA using a Micro AIR@ mesh nebulizer [49]. The authors showed that by using CFD simulation, high strain rates were identified at the exit of the nozzle that can cause damage to the shear sensitive plasmid DNA. The causes of the shear strain were primarily friction around the nozzle wall, reduction of the area during the flow, and compression in the outlet of the nozzle. Strain rates were used to estimate the hydrodynamic force of the plasmid DNA. According to the study, plasmids of $5.7 \mathrm{~kb}$ (kilobase) 
underwent reversible damage, while plasmids of $20 \mathrm{~kb}$ experienced irreversible damage, which was confirmed using experimental measurement.

Different research has been done to study the effects of the nebulization system on drug delivery. $\mathrm{Su}$ et al. declared the advancement of the nebulizer design as one of the most feasible factors in determining effectiveness of drug delivery [63]. The study investigated the feasibility of a valveless micropump by exploring its characteristics and comparing it with a standard nebulizer. A study by Amirav et al. discussed the significance of using add-on devices, such as hood nebulizers and aerosol face masks, on making the drug delivery more desirable $[65,66]$.

A number of researchers used CFD to study the effects of nebulizer device modification on successful drug delivery. According to Lange and Finlay, nebulizers are experiencing a revival and are able to overcome traditional shortcomings through reduced power consumption, effective drug delivery, and reduction in bulkiness due to the development of updated technologies [66]. Nebulizer designs have evolved from manual to electric powered devices and recently vibrating mesh nebulizers. The smart technologies that are emerging have better capacity of lung deposition [48]. In another study reported in [67], it was found that development of interface devices such as facemasks and mouth pieces between the patient and the device are important in order to achieve efficient drug delivery. Worth Longest et al. simulated a mesh nebulizer coupled with add-on devices [68]. The objective of the research was to analyze how submicrometer and nanometer particles were delivered efficiently and to explore their formation from a mesh nebulizer coupled with an add-on device perspective using experimental and CFD techniques. The add-on devices used were found to be very helpful in increasing the effectiveness of the drug delivery by protecting the aerosol from drying by controlling the humidity and temperature of the inhaled aerosol.

Yousefi et al. investigated the CFD simulation of aerosols using an advanced technology called surface acoustic wave (SAW) nebulization [69]. The work stated that conventional aerosol delivery mechanisms have low efficacy, where only a few fractions of the drug intended to be delivered reach the targeted region. As their results indicated, the use of a micropump droplet generator (MDG) and SAW increased the deposition of the drug into the targeted site.

Santati et al. used CFD to analyze the inclusion of a six inch corrugated tube with an $80 \mathrm{~mL}$ capacity in a small volume jet nebulizer (SVJN) so that the device could be used on small asthmatic children [70]. The conventional SVJN was manufactured considering only adults. The device produced a large number of particles with a high speeder than a child could intake. The corrugated tube caused the drugs to slow down by $31.48 \%$, while other important physical attributes remained the same.

In addition to studying the effects of advanced technologies in nebulization, the effects of nozzle geometry, frequency and voltage in determining the effectiveness of the therapy have also been investigated previously [63]. Reported results showed that as the nozzle diameter decreased, particle size decreased as well, and droplet velocity increased. According to [62], going above the optimal frequency resulted in a reduced droplet size, but a larger volume of air was introduced to the reservoir, which caused decreasing ejection performance. Nebulizer flow rate was maximized when the optimal frequency equaled the resonant frequency of the piezoelectrical actuator. In another study, the same nebulizer used by [62] was also used by Shen et al. to investigate the optimal operating conditions of that specific nebulizer [71]. According to the study, the best performance was achieved at $120 \mathrm{kHz}$ working frequency. At that specific frequency, a droplet size of $4 \mu \mathrm{m}$ and a flow rate of $0.5 \mathrm{~mL} / \mathrm{min}$ were achieved

Droplet formation was investigated from a valveless micropump droplet generator (MDG) in another study [63]. The study investigated effects of orifice diameter and frequency on the droplet size and velocity. The results from the study showed that droplet size decreased as the orifice diameter decreased, while droplet velocity decreased as the nozzle diameter increased.

The effect of the third influencing factor, which is patient condition, was investigated by different scholars. Successful therapy depends on the patient's condition. Knowledge of the complex geometric structure of the human respiratory system is needed to estimate the deposition location. The geometry 
is affected by different factors such as sex, weight, height, and age [72]. Shakked et al. simulated the airflow induced drug dispersion through a nebulizer hood to study the effect of patients' breathing conditions on nebulization therapy, focusing on analyzing the dynamics of carrier gas and drug aerosol [73].

Dispersion of drugs through a hood was studied based on three breathing conditions: inspiration, expiration, and apnea. Inside the funnel and the tube that connects the nebulizer with the infants' mouth and near the exit of the funnel, the velocity of the air and trajectories of drug droplets do not have differences among the three breathing phases. However, other parts of the hood highly depend on the infant's breathing condition. Simulation of six consecutive breathing cycles of inspiration, expiration and apnea of four seconds showed that $37 \%$ of the drug reached the patient's mouth, $10.3 \%$ deposited on the head, $13.7 \%$ deposited on the surface under the infant model, and the remaining $39 \%$ exited the hood. Further, the study investigated the effects of different hood designs on drug deposition. One of the findings, for instance, was that efficacy of the drug delivery during inspiration was reduced by $3 \%$ when the funnel was widened [73].

Kim et al. investigated the particle inhalability and deposition on a seven-month old infant model due to changes in head direction and breathing mode [74]. Up, side, and front head directions and nasal and oronasal breathing modes were considered during the study.

Although previous works mainly focused on factors such as drug properties and the nebulization system, the drug delivery process was also highly dependent on patient conditions. Infants usually are nasal breathers, but sometimes due to some problems blocking their nose, they use their mouth. The switch causes deposition of drugs on their faces or eyes. Facial-ocular deposition is highly influenced by head position, but not by the breathing mode. Face side position is considered more preferable than face up position due to lower facial-ocular deposition while achieving similar efficacy, whereas oronasal breathing gives $22.5 \%$ average lung delivery efficiency and nasal breathing offers $18.5 \%$, which agree fairly well with figures reported in vitro measurements previously $(18 \%-20 \%)$.

The effect of nozzle insertion angle inside a patient's mouth on drug delivery was also investigated [75]. The study showed that the angle of insertion mainly affected the momentum of the fluid. That meant it had a stronger effect when the jet velocity was high in the airways, and as a result the aerosol size became larger. Results also showed that the insertion angle at the mouth-inhaler interface also had an effect on the aerosol velocity.

The effects of nasal drug delivery devices and their orientation were numerically analyzed based on the output of an in-house designed automated actuation system producing a spray plume in research by Tong et al. [76]. In order to film and study important characteristics such as cone angle, breaking length, and aerosol velocity, high speed photography was used. These characteristics were used as boundary conditions for the numerical simulation. In the numerical simulation, nasal cavity geometry was obtained from a computed tomography (CT) scan, while different influencing factors like patients' breathing mode, nozzle, and drug droplet were considered. The study showed that the direction of the released particles had effects on the deposition, and the middle direction was found to be the most effective one. Furthermore, Radhakrishnan et al. studied the effects of turbulence produced by the upper air way on the flow and deposition of particles [77]. The flow of air in the trachea and the upper branches of the lung used to be considered laminar in most computer simulations. However, the results reported by Radhakrishnan et al. showed that turbulence due to geometry of the upper airway affected the particle distribution and deposition.

Frank et al. studied the effects of nasal deformity on the penetration of drugs through the nasal valve (NV) using a nebulizer [78]. The study showed that in the presence of septal deviation, particles of $10-\mu \mathrm{m}$ size had good penetration, while particles below $10-\mu \mathrm{m}$ were respirable. As the results indicated, the range of respirable particles sizes in the presence of nasal deformity was different from the normal case.

Table 2 summarizes the different influencing factors of nebulizers studied by different scholars. 
Table 2. Summary of literatures on influencing factors of nebulizers.

\begin{tabular}{|c|c|c|c|c|c|c|}
\hline Authors & Title of Study & Technique & Major Focus & Method Used & $\begin{array}{l}\text { Journal } \\
\text { Impact } \\
\text { Factor }\end{array}$ & $\begin{array}{l}\text { No. of } \\
\text { Citations }\end{array}$ \\
\hline $\begin{array}{c}\text { Worth } \\
\text { Longest et al. } \\
\text { [68] }\end{array}$ & $\begin{array}{l}\text { Production of } \\
\text { Inhalable } \\
\text { Submicrometer } \\
\text { Aerosols from } \\
\text { Conventional } \\
\text { Mesh } \\
\text { Nebulizers for } \\
\text { Improved } \\
\text { Respiratory } \\
\text { Drug Delivery }\end{array}$ & $\begin{array}{c}\text { Mesh } \\
\text { nebulizer }\end{array}$ & $\begin{array}{l}\text { Investigate how } \\
\text { submicron meter } \\
\text { and nanometer } \\
\text { particles are } \\
\text { efficient during } \\
\text { drug delivery and } \\
\text { explore their } \\
\text { formation from } \\
\text { mesh nebulizers }\end{array}$ & $\begin{array}{l}\text { The low Reynolds } \\
\text { number (LRN) K-w } \\
\text { approach was used for } \\
\text { modeling the laminar } \\
\text { flow and Lagrangian } \\
\text { method was used for } \\
\text { particle tracking }\end{array}$ & 2.866 & 69 \\
\hline $\begin{array}{l}\text { Arulmuthu } \\
\text { et al. [49] }\end{array}$ & $\begin{array}{c}\text { Studies on } \\
\text { Aerosol Delivery } \\
\text { of Plasmid DNA } \\
\text { using a Mesh } \\
\text { Nebulizer }\end{array}$ & $\begin{array}{l}\text { MicroAIR } \\
\text { NE-U22 mesh } \\
\text { nebulizer }\end{array}$ & $\begin{array}{l}\text { Aerosolization of } \\
\text { Plasmid DNA } \\
\text { without getting } \\
\text { deformed by the } \\
\text { stress-strain }\end{array}$ & $\begin{array}{l}\text { Assuming laminar flow, } \\
\text { the solution controls } \\
\text { were SIMPLE } \\
\text { pressure-velocity } \\
\text { coupling and second } \\
\text { order pressure with } \\
\text { third-order monotone } \\
\text { upstream-centered } \\
\text { schemes for } \\
\text { conservation laws } \\
\text { (MUSCL) momentum } \\
\text { discretization. } \\
\text { The transient flow } \\
\text { simulations were } \\
\text { carried out using Fluent } \\
\text { 6.2 computational fluid } \\
\text { dynamics } \\
\text { (CFD_commercial code. }\end{array}$ & 4.26 & 45 \\
\hline $\begin{array}{c}\text { Shen et al. } \\
\text { [71] }\end{array}$ & $\begin{array}{c}\text { Design and } \\
\text { Fabrication of } \\
\text { Medical } \\
\text { Micro-Nebulizer }\end{array}$ & $\begin{array}{l}\text { Micropiezo } \\
\text { electrically-actu } \\
\text { nebulizer }\end{array}$ & $\begin{array}{c}\text { The optimal } \\
\text { operating } \\
\text { conditions for } \\
\text { micropiezo, } \\
\text { electrically } \\
\text { actuated } \\
\text { ated nebulizers. } \\
\text { The optimal was } \\
\text { estimated for the } \\
\text { best droplet size } \\
\text { and velocity } \\
\text { output }\end{array}$ & $\begin{array}{l}\text { CFD-RC commercial } \\
\text { code was used for the } \\
\text { CFD simulation while } \\
\text { volume of fluid (VOF) } \\
\text { module was applied to } \\
\text { calculate the ejection } \\
\text { process and grid } \\
\text { deformation module } \\
\text { simulated the vibration } \\
\text { micro-nozzle plate }\end{array}$ & 2.739 & 42 \\
\hline $\begin{array}{c}\text { Frank et al. } \\
{[78]}\end{array}$ & $\begin{array}{c}\text { Effects of } \\
\text { Anatomy and } \\
\text { Particle Size } \\
\text { on Nasal Sprays } \\
\text { and Nebulizers }\end{array}$ & $\begin{array}{c}\text { Not } \\
\text { specified }\end{array}$ & $\begin{array}{l}\text { Effect of a nasal } \\
\text { deformity to the } \\
\text { penetration of } \\
\text { drug through a } \\
\text { nebulizer }\end{array}$ & $\begin{array}{l}\text { ANSYS Fluent } \\
\text { 12.1.4 software bases on } \\
\text { the finite volume } \\
\text { method and discrete } \\
\text { phase model to } \\
\text { calculate particle } \\
\text { trajectories }\end{array}$ & 2.175 & 37 \\
\hline
\end{tabular}


Table 2. Cont.

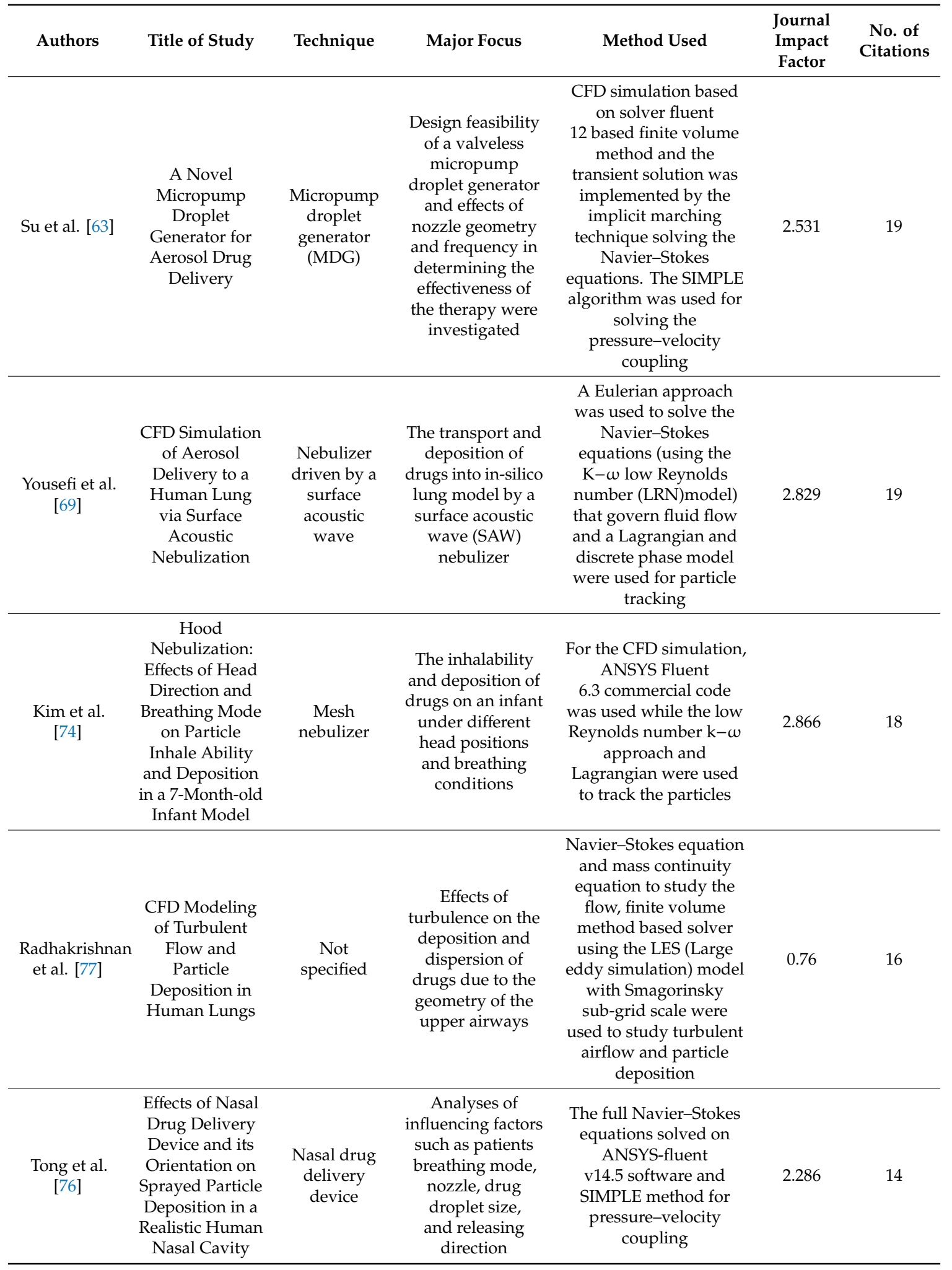


Table 2. Cont.

\begin{tabular}{|c|c|c|c|c|c|c|}
\hline Authors & Title of Study & Technique & Major Focus & Method Used & $\begin{array}{l}\text { Journal } \\
\text { Impact } \\
\text { Factor }\end{array}$ & $\begin{array}{l}\text { No. of } \\
\text { Citations }\end{array}$ \\
\hline $\begin{array}{c}\text { Shakked et } \\
\text { al. [73] }\end{array}$ & $\begin{array}{c}\text { Numerical } \\
\text { Simulation of air } \\
\text { Flow and } \\
\text { Medical-Aerosol } \\
\text { Distribution in } \\
\text { an Innovative } \\
\text { Nebulizer Hood }\end{array}$ & $\begin{array}{l}\text { Nebulizer } \\
\text { with hood }\end{array}$ & $\begin{array}{l}\text { Investigate } \\
\text { numerically the } \\
\text { airflow induced } \\
\text { drug dispersion } \\
\text { inside the hood } \\
\text { and drug droplet } \\
\text { dispersion with } \\
\text { respect to three } \\
\text { breathing phases: } \\
\text { inspiration, } \\
\text { expiration, } \\
\text { and apnea }\end{array}$ & $\begin{array}{c}\text { FLUENT 6.1 CFD } \\
\text { software package } \\
\text { describing the airflow } \\
\text { and the trajectories of } \\
\text { drug droplets to solve } \\
\text { Navier-Stokes equation } \\
\text { and GAMBIT package } \\
\text { to generate geometry } \\
\text { and mesh }\end{array}$ & 2.866 & 9 \\
\hline $\begin{array}{c}\text { Santati et al. } \\
{[70]}\end{array}$ & $\begin{array}{c}\text { Modified } \\
\text { Small-Volume } \\
\text { Jet Nebulizer } \\
\text { Based on CFD } \\
\text { Simulation and } \\
\text { its Clinical } \\
\text { Outcomes in } \\
\text { Small Asthmatic } \\
\text { Children }\end{array}$ & $\begin{array}{l}\text { Small } \\
\text { volume jet } \\
\text { nebulizer } \\
(\mathrm{SVJN})\end{array}$ & $\begin{array}{l}\text { Redesign of SVJN } \\
\text { by adding } \\
\text { corrugated tube in } \\
\text { order to slow } \\
\text { down the drug } \\
\text { velocity so that } \\
\text { they are suitable } \\
\text { for small children }\end{array}$ & $\begin{array}{l}\text { ANSYS Fluent 17.1 CFD } \\
\text { program was used to } \\
\text { solve conservation } \\
\text { equations. The shear } \\
\text { stress transport k- } \omega \\
\text { turbulance model was } \\
\text { used where particle } \\
\text { path lines were } \\
\text { calculated using } \\
\text { discrete phase model }\end{array}$ & 1.295 & 0 \\
\hline
\end{tabular}

\subsection{Droplet Size and Velocity Measurement}

Droplet size and velocity measurements are important in different fields, such as rain droplet measurement. A disdrometer is the most commonly used rain droplet measurement device. Former disdrometer devices used to work based on microscopic measurement. However, the current and most commonly used are optical disdrometers. As discussed earlier, droplet size and velocity are the most important parameters that determine the effectiveness of aerosol therapies. Measurement of these parameters is very important from several points of view including proving reliability and quality of the delivery system and improvement of existing technologies. Most importantly, the results from the measurement can be used as boundary conditions for CFD simulations. There are a number of instruments that are available for measuring spray systems. Therefore, careful consideration must be given to the choice of instruments depending on the application [79]. Although the focus was not medically related, a good review of drop size measurement techniques for dense fuel spray applications was published by A. R. Jones in 1977, which came out in the Journal of Progress in Energy and Combustion Science [80].

Broadly speaking, drop-sizing and velocity measurement techniques can be classified into three groups, namely mechanical, electrical, and optical, each one of them having their subgroups [81-83].

- Mechanical method: In this method, first, droplet samples are directly collected on a solid surface or in a cell containing special fluid. Next, their size is measured through photography or microscopy. There are different types of mechanical methods including droplet capture, cascade impaction and sedimentation techniques. In the droplet capture method, samples of the droplet are collected on a surface where different kinds of surface coatings such as white Vaseline and 
magnesium oxide are applied. Then size of the droplets is determined using a microscope by measuring the mechanical deformation that occurred on the surface coatings by the droplet impact. Although this method is simple, size determination and counting is difficult due to the overlap of droplets on the slides. Besides, the collected sample of droplets might not represent the whole droplet [80]. In case of cascade impactors, the droplet travels with airflow at high velocity and then is impacted with slides coated with a carbon and magnesium oxide mixture, which retains the large droplets, whereas the small droplets will follow the airflow around the slide. As the velocity of the small droplets increases, they will hit the slide, and then after are gathered in a collector. The size of the droplet is then determined by analyzing the cumulative droplet sizes in each slide. This method is convenient for droplet sizes between 1.5 and $50 \mu \mathrm{m}$, whereas droplets larger than $50 \mu \mathrm{m}$ impose problems on the first slide [84]. In the case of the sedimentation method, the spray of droplets is injected into a horizontally moving uniform airflow, which passes through a settling chamber. Then the droplets split up and fall down at varying distances into the settling chamber because of their different terminal velocity and size.

- Electrical: This method depends on the detection and analysis of electronic pulses produced by drops for the construction of drop size distributions. The electrical techniques include the Wicks-Dukler approach, the charged wire probe, and the hot wire anemometer [84]. In the Wicks-Dukler method, the droplet contact frequency between two sharp needles with potential difference is recorded. The distance between the needles is adjustable, and electric contact among them occurs if the droplets are in contact with them simultaneously. In order to monitor the closure frequency, a counter is utilized. The distance between the needles is varied, and closure frequency is measured again and then droplet size distribution is determined. In case of the charged wire method, the droplet is made to hit electrically charged wire, which results in the draw of charge from the wire. The amount of charge drawn from the wire depends on the size of the droplet. In the case of a hot wire anemometer, a drop is captured in a resistively heated wire, which results in the local cooling of the heated wire as the droplet evaporates. Due to this cooling, the wire resistance will fall down. Therefore, in order to restore the resistance to the originally preset value, a voltage pulse is produced, and the analysis of this voltage pulse leads to the droplet size determination [84].

- Optical: includes both imaging (photography, cinematography, holography) and nonimaging (single drop counters, ensemble multi drop counters) techniques.

In the past, cascade impactors were commonly used for measuring the output of inhaler devices [85]. However, spurious deformation was caused due to rapid flow rate and heating effect [86]. Yet the impactors remained as a standard for particle size measurement [64,65]. Nowadays, owing to the introduction of different laser based techniques, measurement has been improved substantially $[87,88]$.

\subsection{Laser Diffraction Analyzer}

Laser diffraction (LD), or Fraunhofer diffraction, is a droplet size measurement technique that operates based on light scattering pattern interpretation, which is subsequently converted into volume weighted droplet size distribution (DSD). Mitchell et al. studied the use of laser diffractometry for measuring aerosol sizes from an inhaler device [89]. The study described the process of changing the light scattering pattern to DSD in three steps (see also Figure 2). 


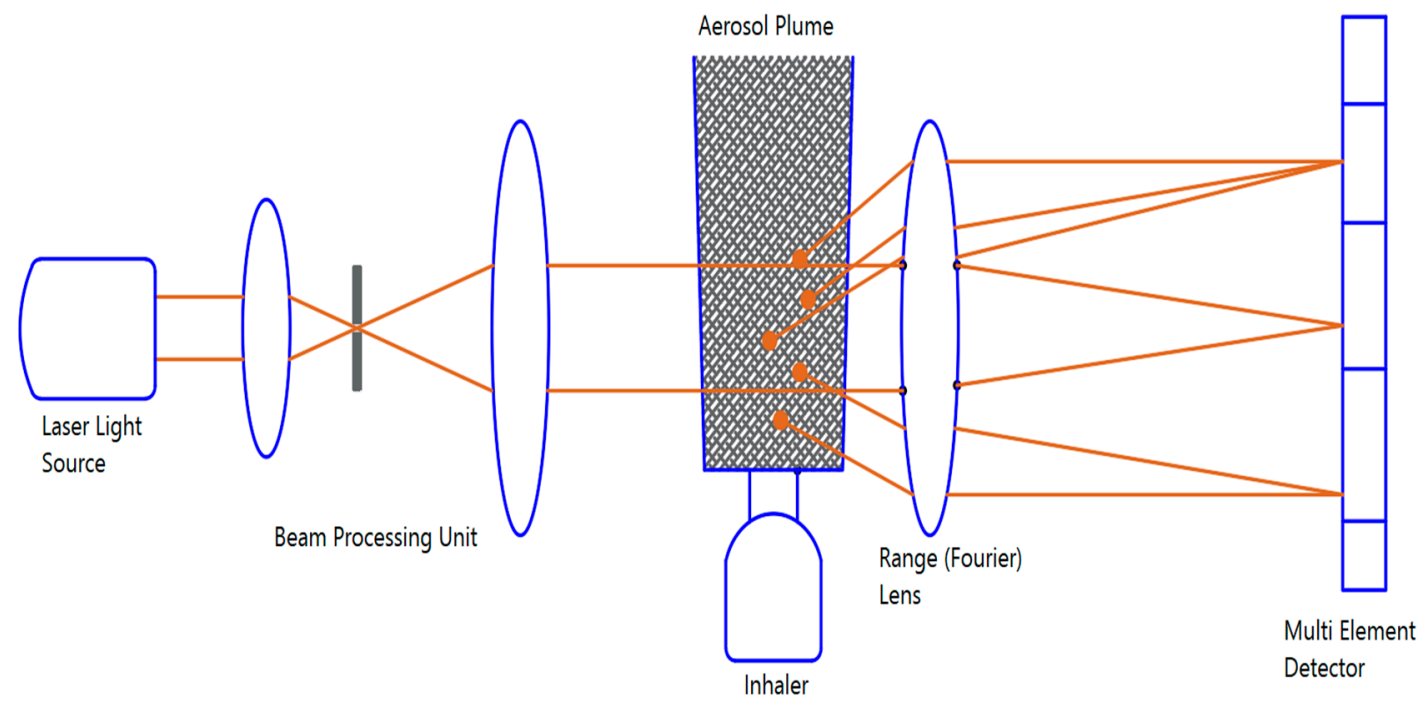

Figure 2. Schematic of a laser diffraction system described in a three step process. In the first step, coherent light is released from the laser diode. The light is then scattered through all the particles and the pattern is detected. Afterwards, the detected pattern is converted to a digital signal and then deconvoluted into droplet size distribution (DSD) [89].

Research has also been carried out comparing the traditional ways of measuring DSD with an LD analyzer [90,91]. The LD technique is considered very fast when it is compared to other former methods. It can take several hundreds of measurements within a one second interval [92-96]. Pilcer et al. described the advantages of LD as a high resolution, short time processing, and automatic data analysis and transfer method [97]. However, the LD technique is not recommended in measuring drug suspensions, since deformation to the drug suspension might occur [97].

\subsection{Laser Doppler Velocimetry}

Laser Doppler velocimetry (LDV), also known as laser Doppler anemometry (LDA), is a technique used to measure the instantaneous velocity of a fluid field using a Doppler shift, which is the frequency difference between the incident and scattered light in a laser beam. A schematic of an LDV system is depicted in Figure 3.

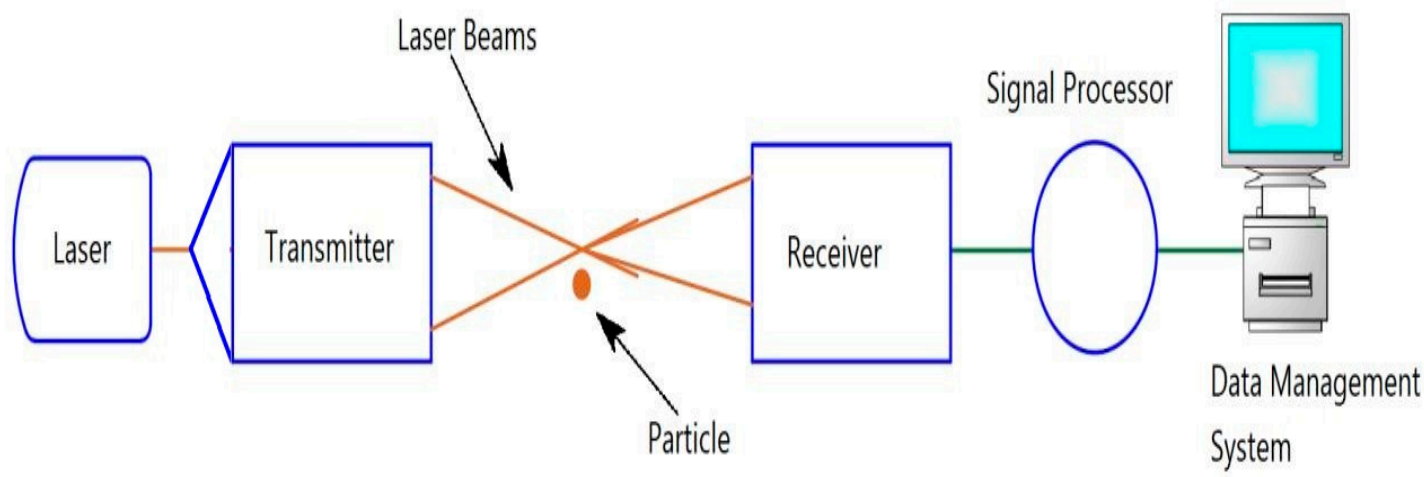

Figure 3. Schematic of a laser Doppler velocimetry system where monochromatic light is emitted towards the target and scattered light is detected by a photo multiple tube (PMT). Then, the Doppler shift is measured, which is a function of the target object relative velocity [98]. 


\subsection{Phase Doppler Anemometer}

The phase Doppler anemometer (PDA), also known as a phase Doppler particle analyzer (PDPA), is an advanced version of an LDV, which is used to measure both the velocity and size of a droplet at the same time $[99,100]$. Figure 4 shows a schematic description of a PDA system.

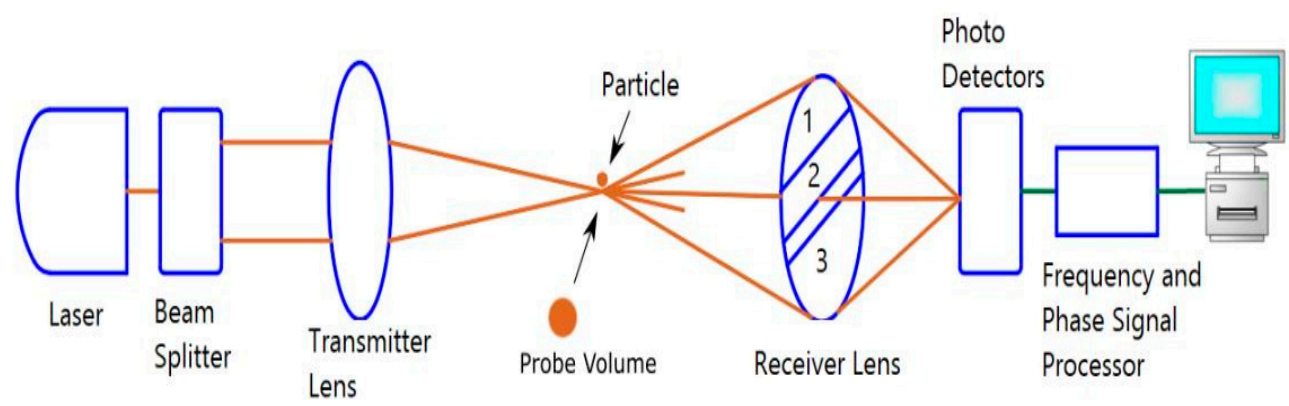

Figure 4. Schematic of a phase Doppler anemometer system making use of two coherent laser lights that are emitted from two beams and intersect at a specific angle to form a measuring volume. The droplet size is measured by analyzing the difference between two bursts detected using different detectors in a different angle, while the velocity is determined by analyzing the Doppler-equivalent frequency of the scattered light through the droplet [101,102].

\section{Discussion}

The literature review in the current study was divided into two parts. In the first part, the analyzed literature implied that the two droplet parameters, i.e. size and velocity, are influenced by different factors, which are grouped into three: particle characteristics, nebulizer system, and patient condition. Physical properties of drugs such as surface tension, viscosity, ionic strength, and $\mathrm{pH}$ have a significant effect on the drug size and velocity. Studies have shown that sensitive drugs such as plasmids are vulnerable for distortion due to their natural structures. This implies that the delivery process must be different for different drugs since they possess discrete characteristics. Research on the second influencing factor, the nebulizer system, indicated that advancements in the design of a nebulizer have an impact on alleviating the efficacy of drug delivery. According to a study by Azevedo et al., which was done on a blurry injector, the nozzle geometry was found to have a significant impact on aerosol production [103]. The study investigated that parameters such as average droplet diameter, discharge coefficient, velocity, and spray cone angel were affected by the nozzle configuration. As the research implies, the change in the configuration of the nozzle has a significant impact on the output. The third factor, which is patient condition and includes breathing condition and insertion angle, also has a significant impact on the delivery process. In addition, respiratory tract deformity and turbulence in the upper airway are other factors that need to be considered for nebulizer device development or enhancement. All the aforementioned factors are not separate, and they are interdependent on one another.

The second part of this literature review was about different techniques of droplet size and velocity measurement. As discussed in the review, results from the measurement are crucial not only for proving reliability and quality of the delivery system and improvement of existing technologies but also are used as boundary conditions during CFD simulations. Commonly used techniques such as LDA, LDV, and PDA were included in the review. The reviewed papers indicated that the use of CFD to study the delivery of aerosolized drugs is growing. This is due to the availability of new software that can provide statistical data from continuity, momentum, and energy equations. Although CFD is complicated, it is much better to study and understand different factors that influence the deposition of drugs than experimental methods. 


\section{Conclusions}

This article reviewed scientific publications on characterization and measurement of medical nebulizers. Administration of drugs in the form of droplets is becoming preferable because it can alleviate the side effects and administration time while increasing the predictability of the drug. The effectiveness of nebulization is mainly determined by DSD and velocity of the droplet. According to the reviews, these parameters are influenced by a number of factors and they were categorized into three groups: particle characteristics, nebulizer system, and patient condition. In order to improve the accuracy and quality of performance, characterization must be done. Nowadays, due to the emergence of powerful software, numerical simulation has become the preferred way of studying the aerosolization process. The other review was on velocity and DSD measurement methods. According to the review, laser based techniques including LDA, LDV, and PDA have been able to make the measurements faster, more accurate, and with better resolution allowing automatic data transfer. In summary, studying characteristics and measurements of aerosolized drugs is very important for analyzing the performance and accuracy of a nebulizer system, whether to design new devices or enhance currently available ones.

Funding: This research was supported by the SPEV project, University of Hradec Kralove, FIM, Czech Republic (ID: 2102-2020), "Smart Solutions in Ubiquitous Computing Environments". The work is partly based on the research supported by National Research Foundation (NRF) grants KIC181128397542 and KIC191008481777.

Acknowledgments: We are grateful for the support of students Sebastien Mambou and Michal Dobrovolny in consultations regarding application aspects. The APC was funded by SPEV project 2020/2102, Faculty of Informatics and Management, University of Hradec Kralove.

Conflicts of Interest: The authors declare no conflict of interest.

\section{References}

1. Merkus, H.G.; Meesters, G.M.H. (Eds.) Production, Handling and Characterization of Particulate Materials; Springer International Publishing: Cham, Switzerland, 2016; Volume 25.

2. Bayvel, L.P.; Orzechowski, Z. Liquid Atomization; Taylor \& Francis: Washington, DC, USA, 1993.

3. Khavkin, Y. The Theory and Practice of Swirl Atomizers; Taylor \& Francis: New York, NY, USA, 2004.

4. Lefebvre, A.H. Atomization and Sprays; Hemisphere Pub. Corp.: New York, NY, USA, 1989.

5. ANSYS FLUENT 12.0 Theory Guide-15.9.2 The Pressure-Swirl Atomizer Model. Available online: http: //www.afs.enea.it/project/neptunius/docs/fluent/html/th/node269.htm (accessed on 18 August 2019).

6. Ang, A.S.M.; Berndt, C.C. A review of testing methods for thermal spray coatings. Int. Mater. Rev. 2014, 59, 179-223. [CrossRef]

7. Zhou, W.; Hu, J.; Feng, M.; Yang, B.; Cai, X. Study on imaging method for measuring droplet size in large sprays. Particuology 2015, 22, 100-106. [CrossRef]

8. $\quad$ Broeders, M.E.A.C.; Sanchis, J.; Levy, M.L.; Crompton, G.K.; Dekhuijzen, P.N.R.; ADMIT Working Group. The ADMIT series-Issues in inhalation therapy. 2. Improving technique and clinical effectiveness. Prim. Care Respir. J. 2009, 18, 76-82. [CrossRef] [PubMed]

9. Smola, M.; Vandamme, T.; Sokolowski, A. Nanocarriers as pulmonary drug delivery systems to treat and to diagnose respiratory and non respiratory diseases. Int. J. Nanomed. 2008, 3, 1-19.

10. Virchow, J.C.; Crompton, G.K.; Dal Negro, R.; Pedersen, S.; Magnan, A.; Seidenberg, J.; Barnes, P.J. Importance of inhaler devices in the management of airway disease. Respir. Med. 2008, 102, 10-19. [CrossRef]

11. Vincken, W.; Dekhuijzen, P.R.; Barnes, P.; ADMIT Group. The ADMIT series-Issues in inhalation therapy. 4) How to choose inhaler devices for the treatment of COPD. Prim. Care Respir. J. 2010, 19, 10-20. [CrossRef] [PubMed]

12. Chrystyn, H.; Price, D. Not all asthma inhalers are the same: Factors to consider when prescribing an inhaler. Prim. Care Respir. J. 2009, 18, 243-249. [CrossRef]

13. Geller, D.E. The science of aerosol delivery in cystic fibrosis. Pediatr. Pulmonol. 2008, 43, S5-S17. [CrossRef]

14. Longest, P.W.; Hindle, M. Evaluation of the Respimat Soft Mist Inhaler using a concurrent CFD and in vitro approach. J. Aerosol Med. Pulm. Drug Deliv. 2009, 22, 99-112. [CrossRef]

15. Newman, S.P.; Wilding, I.R.; Hirst, P.H. Human lung deposition data: The bridge between in vitro and clinical evaluations for inhaled drug products? Int. J. Pharm. 2000, 208, 49-60. [CrossRef] 
16. Finlay, W.H. Estimating the type of hygroscopic behavior exhibited by aqueous droplets. J. Aerosol Med. 1998, 11, 221-229. [CrossRef] [PubMed]

17. Longest, P.W.; Hindle, M.; Choudhuri, S.D. Effects of generation time on spray aerosol transport and deposition in models of the mouth-throat geometry. J. Aerosol Med. Pulm. Drug Deliv. 2009, 22, 67-83. [CrossRef] [PubMed]

18. Coates, M.; Fletcher, D.; Chan, H.-K.; Raper, J. A Comparative Study of Two Marketed Pulmonary Drug Delivery Devices Using Computational Fluid Dynamics; Horwood International Publishing: Bethesda, MD, USA, 2004; pp. 821-824.

19. Tibbatts, J.; Mendes, P.J.; Vlllax, P. Understanding the power requirements for efficient dispersion in powder inhalers: Comparing CFD predictions and experimental measurements. Respir. Drug Deliv. 2010, 1, 323-330.

20. Nichols, S.; Wynn, E. New approaches to optimizing dispersion in dry powder inhalers-dispersion force mapping and adhesion measurements. Respir. Drug Deliv. 2008, 1, 175-184.

21. Tashkin, D.P. A review of nebulized drug delivery in COPD. Int. J. Chron. Obstruct Pulmon. Dis. 2016, 11, 2585-2596. [CrossRef]

22. Martin, A.R.; Finlay, W.H. Nebulizers for drug delivery to the lungs. Expert Opin. Drug Deliv. 2015, 12, 889-900. [CrossRef]

23. Turner, M.O.; Gafni, A.; Swan, D.; FitzGerald, J.M. A review and economic evaluation of bronchodilator delivery methods in hospitalized patients. Arch. Intern. Med. 1996, 156, 2113-2118. [CrossRef]

24. Cates, C.J.; Welsh, E.J.; Rowe, B.H. Holding chambers (spacers) versus nebulisers for beta-agonist treatment of acute asthma. Cochrane Database Syst. Rev. 2013. [CrossRef]

25. Labiris, N.R.; Dolovich, M.B. Pulmonary drug delivery. Part II: The Role of Inhalant Delivery Devices and Drug Formulations in Therapeutic Effectiveness of Aerosolized Medications. Available online: https: //pubmed.ncbi.nlm.nih.gov/14616419/ (accessed on 5 May 2020).

26. Nebuliser systems for drug delivery in cystic fibrosis-Daniels, T-2013 | Cochrane Library. Available online: https://www.cochranelibrary.com/cdsr/doi/10.1002/14651858.CD007639.pub2/full (accessed on 6 May 2020).

27. Tuinman, P.R.; Dixon, B.; Levi, M.; Juffermans, N.P.; Schultz, M.J. Nebulized anticoagulants for acute lung injury-A systematic review of preclinical and clinical investigations. Crit. Care 2012, 16, R70. [CrossRef]

28. Rouby, J.J.; Bouhemad, B.; Monsel, A.; Brisson, H.; Arbelot, C.; Lu, Q. Aerosolized antibiotics for ventilator-associated pneumonia: Lessons from experimental studies. Anesthesiology 2012, 117, 1364-1380. [CrossRef]

29. Boyden, J.Y.; Connor, S.R.; Otolorin, L.; Nathan, S.D.; Fine, P.G.; Davis, M.S.; Muir, J.C. Nebulized medications for the treatment of dyspnea: A literature review. J. Aerosol Med. Pulm. Deliv. Pulm. Drug Deliv. 2015, 28, 1-19. [CrossRef]

30. Finlay, W.H. Pharmaceutical Aerosol Sprays for Drug Delivery to the Lungs. In Handbook of Atomization and Sprays: Theory and Applications; Ashgriz, N., Ed.; Springer US: Boston, MA, USA, 2011; pp. 899-907.

31. Ari, A. Jet, Ultrasonic, and Mesh Nebulizers: An Evaluation of Nebulizers for Better Clinical Outcomes. Euras J. Pulm. 2014, 16, 1-7. [CrossRef]

32. Yeo, L.; Friend, J.; Mcintosh, M.; Meeusen, E.; Morton, D. Ultrasonic Nebulization Platforms for Pulmonary Drug Delivery. Expert Opin. Drug Deliv. 2010, 7, 663-679. [CrossRef]

33. Ari, A.; Restrepo, R.D.; American Association for Respiratory Care. Aerosol delivery device selection for spontaneously breathing patients: 2012. Respir. Care 2012, 57, 613-626. [CrossRef]

34. Ari, A.; Fink, J.B. Guidelines for aerosol devices in infants, children and adults: Which to choose, why and how to achieve effective aerosol therapy. Expert Rev. Respir. Med. 2011, 5, 561-572. [CrossRef]

35. Watts, A.B.; McConville, J.T.; Williams, R.O. Current therapies and technological advances in aqueous aerosol drug delivery. Pharm. Drug Dev. Ind. Pharm. 2008, 34, 913-922. [CrossRef]

36. Taylor, K.M.G.; McCallion, O.N.M. Ultrasonic nebulisers for pulmonary drug delivery. Int. J. Pharm. 1997, 153, 93-104. [CrossRef]

37. Yoshiyama, Y.; Yazaki, T.; Arai, M.; Asai, K.; Kanke, M. The nebulization of budesonide suspensions by a newly designed mesh nebulizer. Respir. Drug Deliv. 2002, 8, 487-489.

38. Elhissi, A.M.A.; Karnam, K.K.; Danesh-Azari, M.-R.; Gill, H.S.; Taylor, K.M.G. Formulations generated from ethanol-based proliposomes for delivery via medical nebulizers. J. Pharm. Pharmacol. 2006, 58, 887-894. [CrossRef] 
39. Elhissi, A.M.A.; Taylor, K.M.G. Delivery of liposomes generated from proliposomes using air-jet, ultrasonic, and vibrating-mesh nebulisers. J. Drug Deliv. Sci. Technol. 2005, 15, 261-265. [CrossRef]

40. Wagner, A.; Vorauer-Uhl, K.; Katinger, H. Nebulization of liposomal rh-Cu/Zn-SOD with a novel vibrating membrane nebulizer. J. Liposome Res. 2006, 16, 113-125. [CrossRef] [PubMed]

41. Myers, T.; Gardenhire, D.; Ari, A.; Hess, D. A Guide to Aerosol Delivery Devices for Respiratory Therapists, 3rd ed.; American Association for Respiratory Care: Irving, TX, USA, 2013.

42. Waldrep, J.C.; Dhand, R. Advanced nebulizer designs employing vibrating mesh/aperture plate technologies for aerosol generation. Curr. Drug Deliv. 2008, 5, 114-119. [CrossRef] [PubMed]

43. Dhand, R. Nebulizers that use a vibrating mesh or plate with multiple apertures to generate aerosol. Respir. Care 2002, 47, 1406-1416.

44. Dolovich, M.B.; Dhand, R. Aerosol drug delivery: Developments in device design and clinical use. Lancet 2011, 377, 1032-1045. [CrossRef]

45. Patton, J.S.; Byron, P.R. Inhaling medicines: Delivering drugs to the body through the lungs. Nat. Rev. Drug Discov. 2007, 6, 67-74. [CrossRef]

46. Hickey, R.D.T. Medical Devices for the Delivery of Therapeutic Aerosols to the Lungs. December 2006. Available online: https://www.rti.org/publication/medical-devices-delivery-therapeutic-aerosols-lungs (accessed on 30 August 2019).

47. Kleinstreuer, C.; Zhang, Z. Airflow and Particle Transport in the Human Respiratory System. Ann. Rev. Fluid Mech. 2010, 42, 301-334. [CrossRef]

48. Carvalho, T.C.; McConville, J.T. The Function and Performance of Aqueous Aerosol Devices for Inhalation Therapy. Available online: https://pubmed.ncbi.nlm.nih.gov/27061412/ (accessed on 5 May 2020).

49. Arulmuthu, E.R.; Williams, D.J.; Baldascini, H.; Versteeg, H.K.; Hoare, M. Studies on aerosol delivery of plasmid DNA using a mesh nebulizer. Biotechnol. Bioeng. 2007, 98, 939-955. [CrossRef]

50. Cheng, Y.S.; Holmes, T.D.; Gao, J.; Guilmette, R.A.; Li, S.; Surakitbanharn, Y.; Rowlings, C. Characterization of nasal spray pumps and deposition pattern in a replica of the human nasal airway. J. Aerosol Med. 2001, 14, 267-280. [CrossRef]

51. Yang, J.Z.; Young, A.L.; Chiang, P.-C.; Thurston, A.; Pretzer, D.K. Fluticasone and budesonide nanosuspensions for pulmonary delivery: Preparation, characterization, and pharmacokinetic studies. J. Pharm. Sci. 2008, 97, 4869-4878. [CrossRef] [PubMed]

52. Chemmalasseri, E.A. Numerical Modelling of Droplet Formation in Mesh Nebulizers. Master's Thesis, Delft University of Technology, Delft, The Nederland, 2012.

53. Haddrell, A.E.; Lewis, D.; Church, T.; Vehring, R.; Murnane, D.; Reid, J.P. Pulmonary aerosol delivery and the importance of growth dynamics. Ther. Deliv. 2017, 8, 1051-1061. [CrossRef] [PubMed]

54. Ashgriz, N. Numerical Techniques for Simulating the Atomization Process; Springer: Boston, MA, USA, 2011; pp. 339-357.

55. Wong, W.; Fletcher, D.; Traini, D.; Chan, H.-K.; Young, P. The use of computational approaches in inhaler development. Adv. Drug Deliv. Rev. 2011, 64, 312-322. [CrossRef] [PubMed]

56. Ruzycki, C.A.; Javaheri, E.; Finlay, W.H. The use of computational fluid dynamics in inhaler design. Expert Opin. Drug Deliv. 2013, 10, 307-323. [CrossRef] [PubMed]

57. Salary, R.R.; Lombardi, J.P.; Samie Tootooni, M.; Donovan, R.; Rao, P.K.; Borgesen, P.; Poliks, M.D. Computational Fluid Dynamics Modeling and Online Monitoring of Aerosol Jet Printing Process. J. Manuf. Sci. Eng. 2017, 139. [CrossRef]

58. Weber, A.; Morlin, G.; Cohen, M.; Williams-Warren, J.; Ramsey, B.; Smith, A. Effect of nebulizer type and antibiotic concentration on device performance. Pediatr. Pulmonol. 1997, 23, 249-260. [CrossRef]

59. Ochowiak, M.; Doligalski, M.; Broniarz-Press, L.; Matuszak, M.; Gosciniak, A. Characterization of sprays for thermo-stabilized pneumatic nebulizer. Available online: https:/pubmed.ncbi.nlm.nih.gov/26825254/ (accessed on 5 May 2020).

60. Broniarz-Press, L.; Ochowiak, M.; Matuszak, M.; Wlodarczak, S. The Effect of Shear and Extensional Viscosity on Atomization in Medical Inhaler. Available online: https://pubmed.ncbi.nlm.nih.gov/24746416/ (accessed on 5 May 2020).

61. Broniarz-Press, L.; Sosnowski, T.R.; Matuszak, M.; Ochowiak, M.; Jablczynska, K. The Effect of Shear and Extensional Viscosities on Atomization of Newtonian and Non-Newtonian Fluids in Ultrasonic Inhaler. Available online: https://europepmc.org/article/med/25735665 (accessed on 5 May 2020). 
62. Jeng, Y.R.; Su, C.C.; Feng, G.H.; Peng, Y.Y. An investigation into a piezoelectrically actuated nebulizer with $\mu$ EDM-made micronozzle array. Exp. Therm. Fluid Sci. 2007, 31, 1147-1156. [CrossRef]

63. Su, G.; Longest, P.W.; Pidaparti, R.M. A novel micropump droplet generator for aerosol drug delivery: Design simulations. Biomicrofluidics 2010, 4, 044108. [CrossRef]

64. Amirav, I.; Oron, A.; Tal, G.; Cesar, K.; Ballin, A.; Houri, S.; Naugolny, L.; Mandelberg, A. Aerosol delivery in respiratory syncytial virus bronchiolitis: Hood or face mask? J. Pediatr. 2005, 147, 627-631. [CrossRef]

65. Amirav, I.; Balanov, I.; Gorenberg, M.; Groshar, D.; Luder, A.S. Nebuliser hood compared to mask in wheezy infants: Aerosol therapy without tears! Arch. Dis. Child. 2003, 88, 719-723. [CrossRef] [PubMed]

66. Lange, C.F.; Finlay, W.H. Liquid atomizing: Nebulizing and other methods of producing aerosols. J. Aerosol Med. 2006, 19, 28-35. [CrossRef]

67. Finlay, W.H.; Martin, A.R. Modeling of aerosol deposition with interface devices. J. Aerosol Med. 2007, 20 (Suppl. 1), S19-S26; [CrossRef] [PubMed]

68. Longest, P.W.; Spence, B.M.; Holbrook, L.; Mossi, T.; K. Son, M.Y.J.; Hindle, M. Production of inhalable submicrometer aerosols from conventional mesh nebulizers for improved respiratory drug delivery. Available online: https://pubmed.ncbi.nlm.nih.gov/22707794/ (accessed on 5 May 2020).

69. Yousefi, M.; Pourmehran, O.; Gorji-Bandpy, M.; Inthavong, K.; Yeo, L.; Tu, J. CFD simulation of aerosol delivery to a human lung via surface acoustic wave nebulization. Biomech. Model Mechanobiol. 2017, 16, 2035-2050. [CrossRef]

70. Santati, S.; Thongsri, J.; Sarntima, P. Modified Small-Volume Jet Nebulizer Based on CFD Simulation and Its Clinical Outcomes in Small Asthmatic Children. J. Healthc. Eng. 2019. Available online: https: //www.hindawi.com/journals/jhe/2019/2524583/ (accessed on 10 December 2019).

71. Shen, S.-C.; Wang, Y.-J.; Chen, Y.-Y. Design and fabrication of medical micro-nebulizer. Sens. Actuators A Phys. 2008, 144, 135-143. [CrossRef]

72. Pirozynski, M.; Sosnowski, T.R. Inhalation devices: From Basic Science to Practical Use, Innovative vs. Generic Products. Available online: https://pubmed.ncbi.nlm.nih.gov/27267298/ (accessed on 5 May 2020).

73. Shakked, T.; Katoshevski, D.; Broday, D.M.; Amirav, I. Numerical simulation of air flow and medical-aerosol distribution in an innovative nebulizer hood. J. Aerosol Med. 2005, 18, 207-217. [CrossRef] [PubMed]

74. Kim, J.; Xi, J.; Si, X.; Berlinski, A.; Su, W.C. Hood nebulization: Effects of head direction and breathing mode on particle inhalability and deposition in a 7-month-old infant model. J. Aerosol Med. Pulm. Deliv. Pulm. Drug Deliv. 2014, 27, 209-218. [CrossRef]

75. Delvadia, R.R.; Longest, P.W.; Hindle, M.; Byron, P.R. In vitro tests for aerosol deposition. III: Effect of inhaler insertion angle on aerosol deposition. J. Aerosol Med. Pulm. Deliv. Pulm. Drug Deliv. 2013, 26, 145-156. [CrossRef]

76. Tong, X.; Dong, J.; Shang, Y.; Inthavong, K.; Tu, J. Effects of nasal drug delivery device and its orientation on sprayed particle deposition in a realistic human nasal cavity. Comput. Biol. Med. 2016, 77, 40-48. [CrossRef]

77. Radhakrishnan, H.; Kassinos, S. CFD modeling of turbulent flow and particle deposition in human lungs. In Proceedings of the 2009 Annual International Conference of the IEEE Engineering in Medicine and Biology Society, Minneapolis/St. Paul, MN, USA, 2-6 September 2009; pp. 2867-2870. [CrossRef]

78. Frank, D.O.; Kimbell, J.S.; Pawar, S.; Rhee, J.S. Effects of anatomy and particle size on nasal sprays and nebulizers. Otolaryngol. Head Neck Surg. 2012, 146, 313-319. [CrossRef]

79. Optical Imaging of Sprays—ScienceDirect. Available online: https://www.sciencedirect.com/science/article/ pii/036012859190011B (accessed on 12 August 2019).

80. Lefebvre, A.H.; McDonell, V.G. Atomization and Sprays; CRC Press: Boca Raton, FL, USA, 2017.

81. Finlay, W.; Stapleton, K. Undersizing of droplets from a vented nebulizer caused by aerosol heating during transit through an Anderson impactor. J. Aerosol Sci. 1999, 30, S0021-S8502. [CrossRef]

82. Dennis, J.; Berg, E.; Sandell, D.; Ali, A.; Lamb, P.; Tservistas, M.; Karlsson, M.; Mitchell, J. Cooling the NGI-an approach to size a nebulised aerosol more accurately. Pharmeur Sci. Notes 2008, 2008, 27-30.

83. Kwong, W.T.; Ho, S.L.; Coates, A.L. Comparison of nebulized particle size distribution with Malvern laser diffraction analyzer versus Andersen cascade impactor and low-flow Marple personal cascade impactor. J. Aerosol Med. 2000, 13, 303-314. [CrossRef] [PubMed]

84. Jones, A.R. A review of drop size measurement-The application of techniques to dense fuel sprays. Prog. Energy Combust. Sci. 1977, 3, 225-234. [CrossRef] 
85. Mitchell, J.P.; Nagel, M.W. Cascade impactors for the size characterization of aerosols from medical inhalers: Their uses and limitations. J. Aerosol Med. 2003, 16, 341-377. [CrossRef] [PubMed]

86. Gurses, B.K.; Smaldone, G.C. Effect of tubing deposition, breathing pattern, and temperature on aerosol mass distribution measured by cascade impactor. J. Aerosol Med. 2003, 16, 387-394. [CrossRef] [PubMed]

87. Laube, B.L.; Janssens, H.M.; de Jongh, F.H.; Devadason, S.G.; Dhand, R.; Diot, P.; Everard, M.L.; Horvath, I.; Navalesi, P.; Voshaar, T.; et al. What the pulmonary specialist should know about the new inhalation therapies. Eur. Respir. J. 2011, 37, 1308-1331. [CrossRef]

88. McCallion, O.N.M.; Taylor, K.M.G.; Thomas, M.; Taylor, A.J. The Influence of Surface Tension on Aerosols Produced By Medical Nebulisers International. J. Pharm. 1996, 129, 123-136.

89. Mitchell, J.P.; Nagel, M.W.; Nichols, S.; Nerbrink, O. Laser diffractometry as a technique for the rapid assessment of aerosol particle size from inhalers. J. Aerosol Med. 2006, 19, 409-433. [CrossRef]

90. Pilcer, G.; Vanderbist, F.; Amighi, K. Correlations between cascade impactor analysis and laser diffraction techniques for the determination of the particle size of aerosolised powder formulations. Int. J. Pharm. 2008, 358, 75-81. [CrossRef]

91. Lelong, N.; Junqua-Moullet, A.; Diot, P.; Vecellio, L. Comparison of laser diffraction measurements by mastersizer $\mathrm{X}$ and spraytec to characterize droplet size distribution of medical liquid Aerosols. J. Aerosol Med. Pulm. Drug Deliv. 2014, 27, 94-102. [CrossRef]

92. Kippax, P.W. Appraisal of the Laser Diffraction Particle-Sizing Technique. Pharm. Technol. 2005, 3, 88-89.

93. Etzler, F.M.; Deanne, R. Particle size analysis: A comparison of various methods ii. Part. Syst. Charact. 1997, 14, 278-282. [CrossRef]

94. FDA (CDRH). Reviewer Guidance for Nebulizers, Metered Dose Inhalers, Spacers and Actuators. U.S. Food and Drug Administration. 1993. Available online: http://www.fda.gov/regulatory-information/searchfda-guidance-documents/reviewer-guidance-nebulizers-metered-dose-inhalers-spacers-and-actuators (accessed on 25 June 2019).

95. FDA (CDRH). Bioavailability and Bioequivalence Studies for Nasal Aerosols and Nasal Sprays for Local Action; Center for Drug Evaluation and Research: Rockville, MD, USA, 2003; p. 37.

96. ISO13320-1. Particle Size Analysis_Laser Diffraction Methods. Part 1, General Principles; BSI: London, UK, 1999.

97. Jones, S.A.; Martin, G.P.; Brown, M.B. High-pressure aerosol suspensions-A novel laser diffraction particle sizing system for hydrofluoroalkane pressurised metered dose inhalers. Int. J. Pharm. 2005, 302, 154-165. [CrossRef] [PubMed]

98. Wilson, J.C.; Liu, B.Y.H. Aerodynamic particle size measurement by laser-doppler velocimetry. J. Aerosol Sci. 1980, 11, 139-150. [CrossRef]

99. Doughty, D.V.; Vibbert, C.; Kewalramani, A.; Bollinger, M.E.; Dalby, R.N. Automated actuation of nasal spray products: Determination and comparison of adult and pediatric settings. Pharm. Drug Dev. Ind. Pharm. 2011, 37, 359-366. [CrossRef] [PubMed]

100. Kippax, P.; Krarup, H.; Suman, J.D. Application for droplet sizing: Manual versus automated actuation of nasal sprays. Pharm. Technol. 2004, 28, 30-40.

101. Liu, X.F.; Doub, W.H.; Guo, C.N. Evaluation of droplet velocity and size from nasal spray devices using phase Doppler anemometry (PDA). Int. J. Pharm. 2010, 388, 82-87. [CrossRef]

102. Albrecht, H.-E.; Borys, M.; Damaschke, N.; Tropea, C. Laser Doppler and Phase Doppler Measurement Techniques; Springer Science \& Business Media: Berlin/Heidelberg, Germany, 2013; pp. 9-26.

103. Azevedo, C.; Costa, F.; Andrade, J.C. Effects of nozzle exit geometry on spray characteristics of a blurry injector. At. Sprays 2013, 23. [CrossRef]

(C) 2020 by the authors. Licensee MDPI, Basel, Switzerland. This article is an open access article distributed under the terms and conditions of the Creative Commons Attribution (CC BY) license (http://creativecommons.org/licenses/by/4.0/). 